\title{
Slurry Sampling for Arsenic Determination in Sediments by Hydride Generation Atomic Absorption Spectrometry
}

\author{
Daiane P. Torres, Mariana A. Vieira, ${ }^{*}$ Anderson S. Ribeiro and Adilson J. Curtius \\ Departamento de Química, Universidade Federal de Santa Catarina, 88040-900, Florianópolis-SC, Brazil
}

\begin{abstract}
Um método simples e robusto para a determinação de arsênio em sedimentos por espectrometria de absorção atômica com geração de hidreto (HG-AAS) usando a amostragem em suspensão é proposto. Água régia $(5 \% \mathrm{v} / \mathrm{v})$ e ácido fluorídrico $(1 \% \mathrm{v} / \mathrm{v})$ foram misturados a uma alíquota do sedimento com tamanho de partícula $50 \mu \mathrm{m}$ e colocados no banho ultrasônico por $30 \mathrm{~min}$. A suspensão foi deixada em repouso por $48 \mathrm{~h}$ para uma extração eficaz do analito para a fase aquosa. $\mathrm{O}$ volume final da suspensão foi ajustado com $\mathrm{HCl} 1 \mathrm{~mol} \mathrm{~L}^{-1}$. Uma solução de $\mathrm{NaBH}_{4}$ estabilizada com $\mathrm{NaOH}$ foi usada como agente redutor. A arsina foi transportada ao tubo $\mathrm{T}$ de quartzo aquecido a $900{ }^{\circ} \mathrm{C}$ para detecção. Cinco materiais de referência certificados de sedimento foram analisados e as concentrações obtidas foram concordantes com os valores certificados, de acordo com o teste- $t$ para um nível da confiança de $95 \%$, com RSD (desvio padrão relativo) menor que 13\%. O limite de detecção (LOD) na amostra foi de $0,6 \mu \mathrm{g} \mathrm{g}^{-1}$. O procedimento proposto para a determinação de arsênio em sedimentos é preciso, exato e adequado para a análise de rotina de amostras ambientais.
\end{abstract}

A simple and robust method for the determination of arsenic in sediments by hydride generation atomic absorption spectrometry (HG-AAS) using slurry sampling is proposed. Aqua regia $(5 \% \mathrm{v} / \mathrm{v})$ and hydrofluoric acid $(1 \% \mathrm{v} / \mathrm{v})$ were mixed with an aliquot of the sediment with particle size of $50 \mu \mathrm{m}$ in an ultrasonic bath for $30 \mathrm{~min}$. The slurry was allowed to stand for 48 $\mathrm{h}$ for an effective extraction of the analyte to the aqueous phase. The final volume of the slurry was made up with $\mathrm{HCl} 1 \mathrm{~mol} \mathrm{~L}^{-1}$. $\mathrm{A} \mathrm{NaBH}_{4}$ solution stabilized with $\mathrm{NaOH}$ was used as reducing agent. The arsine was transported to the quartz T-tube heated at $900{ }^{\circ} \mathrm{C}$ for detection. Five certified reference materials of sediment were analyzed and the obtained concentrations were in good agreement with the certified values, according to the $t$-test for a $95 \%$ confidence level with RSD (relative standard deviation) lower than $13 \%$. The limit of detection (LOD) in the sample was $0.6 \mu \mathrm{g} \mathrm{g}^{-1}$. The proposed procedure for arsenic determination in sediment is precise, accurate and adequate for the environmental samples routine analyses.

Keywords. arsenic, sediment, slurry sampling, hydride generation, atomic absorption spectrometry

\section{Introduction}

The presence of arsenic (As) in the environment and in food comes from natural sources or anthrogenic effects, such as in agriculture and in wood conservation. Especially important are the thermoelectric power plants emissions, in which arsenic is a by-product launched to the atmosphere and to the ground. The sediments act as a deposit and also as a source of pollution for the aquatic environment, because trace elements may be transformed into soluble and potentially more toxic species through

*e-mail: maryanavieira@hotmail.com degradation or reaction. It is very important to know the concentration of potentially hazardous trace elements, such as arsenic, due to its environmental problems. ${ }^{1-4}$

Several analytical techniques and procedures for quantification of trace elements, usually in low concentrations in environmental samples, are applicable to arsenic determination. The hydride generation (HG) is a highly efficient sample introduction technique for atomic absorption spectrometry (AAS). Usually, HG technique is based on the reaction of $\mathrm{NaBH}_{4}$ with the acidified sample and the separation of the analyte, as an hydride from the matrix before measurement. This is one of its main advantage, as it significantly reduces the possibility of interferences. ${ }^{5,6} \mathrm{An}$ alternative to chemical reduction with $\mathrm{NaBH}_{4}$ has been 
reported by Guo et al. ${ }^{7,8}$ who described the generation of volatile forms of a number of elements by photoreduction. This process can be detected by inductively coupled plasma mass spectrometry (ICP-MS) and uses organic acids with low molecular weight to promote the production of radicals that generate volatile species of the analyte. However, this procedure should not be easily applicable to slurries that are prepared with mineral acids.

The sample preparation procedures for arsenic determination are very critical because of its high volatility. Usually, sediments are brought into solution using alkaline fusion or acid digestion before trace element determination, but these procedures are time consuming and require relatively high amounts of reagents. However, this can introduce contaminants to the sample solution and loss of volatile elements, like arsenic. Slurry sampling seems to be an attractive alternative for sample preparation. Partial extraction of the analyte into the slurry water phase is obtained, thereby improving the precision. Particle size, acid nature and concentration and calibration are important factors to be considered when slurry sampling is employed. In addition, sonication helps homogenization and extraction of the analyte and other components from the particles into the slurry water phase. ${ }^{9}$ Alves et al. ${ }^{10,11}$ carried out the determination of $\mathrm{Cu}, \mathrm{Fe}, \mathrm{Mn}$ and $\mathrm{Zn}$ in Antarctic krilland $\mathrm{Cu}, \mathrm{Pb}$ and $\mathrm{Zn}$ in sediment, using slurry sampling in combination with flame atomic absorption spectrometry. Borges et al. ${ }^{12}$ used slurry sampling for the determination of $\mathrm{Cd}$ in sediment and sewage sludge by electrothermal atomic absorption spectrometry using Ir as a permanent modifier. Ribeiro et al..$^{13}$ reported that slurry sampling can also be successfully applied to determine $\mathrm{Hg}$ in different environmental samples (sediments, sewage sludge, coal and coal fly ash) by cold vapor atomic absorption spectrometry using a batch system and a quartz T-tube.

In 1988, Haswell et al. ${ }^{14}$ investigated a procedure using slurry sampling to determine As in soils, sewage sludge and fly ash samples by HG-AAS. The samples were prepared using $\mathrm{HCl}$ at room temperature. However, the developed procedure did not show satisfactory results for quantitative analyses, as the recoveries of the expected concentration values were too low: between $22.1 \%$ and $62.1 \%$. Mierzwa and Dobrowolski ${ }^{15}$ also developed procedures for arsenic determination in sediment sample using a slurry prepared with nitric acid, followed by application of ultrasonic energy and microwave to extract the analyte to the liquid phase. However, this procedure needed the addition of L-cysteine to reduce $\mathrm{As}(\mathrm{V})$ to $\mathrm{As}(\mathrm{III})$ before the determination in the supernatant. Due to the several steps mentioned, Gürleyük et al. ${ }^{16}$ developed a procedure using flow injection to speed up and simplify the procedure.
The use the graphite furnace for in situ retention and determination of the hydride-forming element, denominated HG-GF AAS is more recent. ${ }^{17}$ The possibility of pre-concentrating the hydride generated from a large sample volume and, particularly, from slurry or from multiple sample aliquots in the graphite tube, followed by a single release of the trapped analyte by heating the furnace, is an interesting approach. Matusiewicz and Mroczkowska ${ }^{18}$ proposed a slurry sampling hydride generation method for As(III) and total inorganic arsenic determinations, using slurry sampling with ultrasonication and ozonation. The species of arsenic were trapped on a pre-heated graphite furnace at $300{ }^{\circ} \mathrm{C}$, treated with $150 \mu \mathrm{g}$ of iridium as chemical permanent modifier and determined by graphite furnace atomic absorption spectrometry.

Recently, Vieira et al. ${ }^{19}$ proposed a method to determine As in sediments, coal and fly ash slurries after ultrasonic treatment by HG-GF AAS and trapping in an iridium-treated graphite tube. After grinding the samples to a particle size of $\leq 50 \mu \mathrm{m}$, the sample powder was mixed with aqua regia and hydrofluoric acid in an ultrasonic bath for $30 \mathrm{~min}$. The LODs for arsenic in the samples were 0.5 and $0.7 \mu \mathrm{g} \mathrm{g}^{-1}$ for the coal and sediment samples, respectively.

The purpose of this work was the development of a simple and robust method for arsenic determination in sediment using slurry sampling and detection by HG-AAS with a quartz T-tube heated in an air-acetylene flame. The conditions used in the slurry preparation and in the hydride generation were optimized.

\section{Experimental}

\section{Instrumentation}

All measurements were carried out using an AAnalyst 100 atomic absorption spectrometry (Perkin Elmer, Norwalk, CT, USA), equipped with a deuterium arc background correction and with an arsenic cathode lamp under the following operating conditions: wavelength, 193.7 $\mathrm{nm}$; spectral resolution, $0.7 \mathrm{~nm}$ and applied current, $18 \mathrm{~mA}$. A chemical vapor generator system MHS 15 (from Perkin Elmer) coupled to the AAnalyst 100 was manually operated. A $3 \% \mathrm{~m} / \mathrm{v}$ sodium borohydride solution stabilized with $1 \%$ $\mathrm{m} / \mathrm{v}$ sodium hydroxide was used as reducing agent. The reducing agent was injected during $10 \mathrm{~s}$. The sample volume was $1 \mathrm{~mL}$. Argon with a purity of $99.996 \%$ (White Martins, São Paulo, Brazil) was used as the carrier gas for the arsine, at a pressure of $250 \mathrm{kPa}$, as recommended by the equipment manual. For the arsenic determination, a quartz T-tube 
cell with a path-length of $165 \mathrm{~mm}$ and a diameter of 12 $\mathrm{mm}$ was heated to approximately $900{ }^{\circ} \mathrm{C}$ in an air-acetylene flame, with gas flow rates of $7.0 \mathrm{~L} \mathrm{~min}^{-1}$ (air) and $1.5 \mathrm{~L}$ $\min ^{-1}$ (acetylene). Integrated absorbance (peak area) was used for signal evaluation. Samples slurries were sonicated using a Model T7 ultrasonic bath (Thorton, SP, Brazil) at room temperature.

\section{Reagents and references materials}

All chemicals used were of analytical reagent grade and the solutions were prepared using high-purity water with a resistivity of $18.2 \mathrm{M} \Omega \mathrm{cm}$, obtained from a MilliQ Plus water purification system (Millipore, Bedford, MA). The nitric acid (Carlo Erba, Milan, Italy) and the hydrochloric acid (Merck, Darmstadt, Germany) were doubly distilled in a quartz sub-boiling apparatus (Kürner Analysentechnik, Rosenheim, Germany). Hydrofluoric acid (Merck) was purified by distillation in a PTFE subboiling still (Kürner Analysentechnik). The reductant, a $3.0 \% \mathrm{~m} / \mathrm{v}$ sodium tetrahydroborate solution, was prepared by dissolving $\mathrm{NaBH}_{4}$ (Merck) in $1.0 \% \mathrm{~m} / \mathrm{v} \mathrm{NaOH}$ (Merck) and stored in a polyethylene flask under refrigeration. The calibration solutions with concentrations of 5.0 to 50.0 $\mu \mathrm{g} \mathrm{L}^{-1}$ of arsenic were obtained by appropriate dilution of a stock standard solution of arsenic, which was prepared from high-purity $\mathrm{As}_{2} \mathrm{O}_{3}$ (Spex, Metuchen, NJ) for As(III). The following certified reference materials were used: PACS-2 and MESS-2 marine sediments (National Research Council of Canada, Ottawa, ON, Canada), SRM 2704 Buffalo River sediment and SRM 1646a estuarine sediment (National Institute of Standards \& Technology, NIST, Gaithersburg, MD, USA), and RS-3 river sediment, from a round robin test. ${ }^{20}$

Plastic and glass containers were washed with tap water and diluted Extran solution (Merck), kept in contact with $10.0 \% \mathrm{v} / \mathrm{v} \mathrm{HNO}_{3}$ for at least $48 \mathrm{~h}$ and rinsed three times with deionized water prior to the use.

\section{Slurry preparation}

Based on the work of Vieira et al., ${ }^{19}$ the following procedure was tested. All reference materials were ground in an agate mortar and passed through a $50 \mu \mathrm{m}$ polyester sieve (SEFAR ${ }^{\circledR}$, Switzerland). Approximately, an amount of $50 \mathrm{mg}$ of the ground and sieved sample was mixed with 2.5 $\mathrm{mL}$ of concentrated aqua regia and $0.5 \mathrm{~mL}$ of concentrated hydrofluoric acid in a $50 \mathrm{~mL}$ polyethylene flask, except for SRM 1646a, which was made up to $15 \mathrm{~mL}$ and placed in an ultrasonic bath for $30 \mathrm{~min}$. The slurry was allowed to stand at room temperature for $48 \mathrm{~h}$ under occasional shaking. Then the final volume was completed with $1.0 \mathrm{~mol} \mathrm{~L}^{-1} \mathrm{HCl}$, and the slurry was manually agitated for $30 \mathrm{~s}$, just before the determination, to assure homogeneity. In this way, the final concentration of the acids in the slurry was $5.0 \% \mathrm{v} / \mathrm{v}$ aqua regia, $1.0 \% \mathrm{v} / \mathrm{v}$ hydrofluoric acid and $8.3 \% \mathrm{v} / \mathrm{v}$ hydrochloric acid. These concentrations of acid were optimized previously ${ }^{19}$ and the results confirmed that these amounts are sufficient to react with the sample and promote partial extraction of the analyte to the liquid phase.

\section{Analytical procedure}

A volume of $1 \mathrm{~mL}$ slurry aliquot was placed into the reaction flask of the MHS-15 system and the reducing solution $\left(\mathrm{NaBH}_{4}\right)$ was added for $10 \mathrm{~s}$. The arsine vapor generated was transported to the heated quartz T-tube cell adjusted to the AAS spectrometer. Calibration was carried out using aqueous standard solutions with As(III) in the concentration range of 5.0-50.0 $\mathrm{g} \mathrm{L}^{-1}$, containing the same acid concentrations as in the slurries $(5.0 \% \mathrm{v} / \mathrm{v}$ aqua regia, $1.0 \% \mathrm{v} / \mathrm{v} \mathrm{HF}$ and $8.3 \% \mathrm{v} / \mathrm{v} \mathrm{HCl})$.

\section{Results and Discussion}

\section{Hydride generation system}

The batch system used for the hydride generation is of commercial origin, being all parameters optimized by the manufacturer for the analysis of aqueous solutions in diluted acid media. Some conditions, such as sample volume and concentration of the reducing solution were re-optimized for the slurries, using three certified reference materials of sediment: PACS-2, SRM 2704 and SRM 1646a.

Firstly, the sample volume in the reaction vessel was evaluated. The volume of slurry, of course, can significantly affect the sensitivity of the method using hydride generation. The effect of the volume of slurry was studied in the range from 1 to $5 \mathrm{~mL}$ using slurries of different sediments. As it is shown in Figure 1, large volumes of slurry produce integrated absorbance signal intensities above 1 . A volume of $1 \mathrm{~mL}$ of slurry was adopted for the analyses.

The effect of the $\mathrm{NaBH}_{4}$ concentration on the As absorbance signal was studied in the range from from 0.5 to $6.0 \% \mathrm{~m} / \mathrm{v}$ using slurries of sediment, as it can be observed in Figure 2. The integrated absorbance signal for As in the slurries increases with the increase of $\mathrm{NaBH}_{4}$ concentration up to $1.5 \% \mathrm{~m} / \mathrm{v}$, leveling off for higher concentration of the reducing solution, hence, a concentrations of $3 \% \mathrm{~m} / \mathrm{v}$ of $\mathrm{NaBH}_{4}$, stabilized with $1 \% \mathrm{~m} / \mathrm{v}$ of $\mathrm{NaOH}$, was adopted for further experiments. 


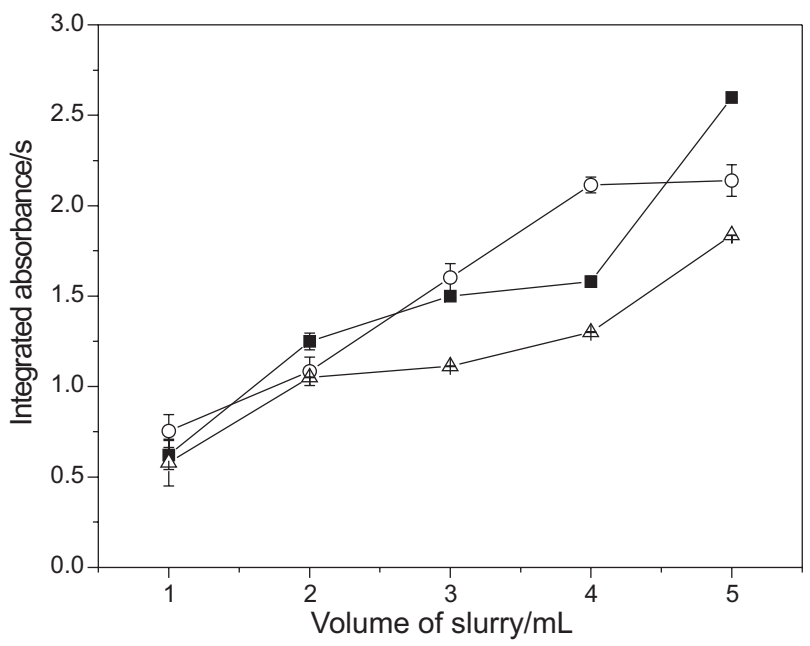

Figure 1. Effect of slurry volume on the integrated absorbance signal by HG AAS for As in the slurries of different certified sediments. (- - -) PACS-2 25.8 $\mu \mathrm{g} \mathrm{L}{ }^{-1}$, (-O-) SRM $270423.9 \mu \mathrm{g} \mathrm{L}-1$ and (- $\triangle$-) SRM 1646a $21.0 \mu \mathrm{g} \mathrm{L}-1$ mean \pm standard derivation, $\mathrm{n}=3$.

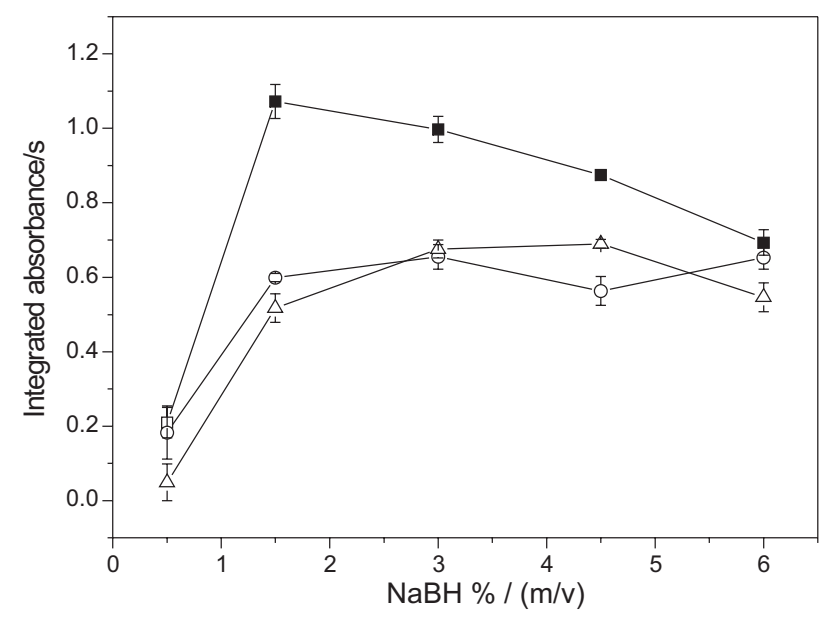

Figure 2. Effect of $\mathrm{NaBH}_{4}$ concentration on the integrated absorbance signal for As in the slurries of different certified sediments. (-口-) PACS-2 $25.8 \mu \mathrm{g}$ $\mathrm{L}^{-1}$, (-O-) SRM $270423.6 \mu \mathrm{g} \mathrm{L}^{-1}$ and (- $\triangle$-) SRM 1646a $20.6 \mu \mathrm{g} \mathrm{L}^{-1}$.

\section{Effect of the slurry preparation time}

A mixture of aqua regia and hydrofluoric acid was used in the slurry preparation, with the intention of improving the extraction of the analyte to the aqueous phase, in order to reach a better precision. ${ }^{19}$ Certainly, the reactions with $\mathrm{NaBH}_{4}$ during the hydride generation, after the slurry preparation, contributes for the extraction. The use of hydrofluoric acid is justified by the usually high silica content in sediments.

The slurries were allowed to stand at room temperature for $0,15,24$ and $48 \mathrm{~h}$. The As recoveries related to the certified values, as shown in Figure 3, were not satisfactory for all samples when time was 0,15 or $24 \mathrm{~h}$, indicating that part of the As was not released from the solid particles, even under the reactions of the vapor generation. Using a standing time of $48 \mathrm{~h}$, all samples shown about $100 \%$ recovery. Thus, the sediment slurries were prepared using $5.0 \% \mathrm{v} / \mathrm{v}$ aqua regia and $1.0 \% \mathrm{v} / \mathrm{v} \mathrm{HF}$ and a standing time of $48 \mathrm{~h}$ to promote an effective extraction of the analyte to the liquid phase. According to previous work, ${ }^{19}$ the As recovery in the acid liquid phase of the slurries, obtained after centrifugation, were in the range $59-96 \%$ in five certified sediments, demonstrating that quantitative analysis should be carried out in the slurry and not in its liquid phase.

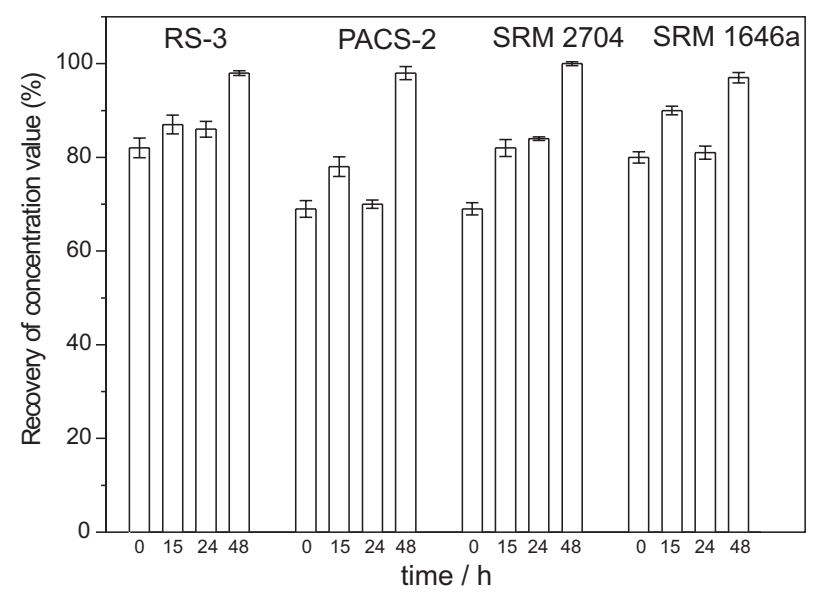

Figure 3. Effect of time preparation of the slurries on the recoveries of the certified values for As in the slurries of different certified sediments mean \pm standard derivation, $\mathrm{n}=3$.

According to Petrick and Krivan, ${ }^{21}$ a concentration of up to $1 \% \mathrm{v} / \mathrm{v}$ HF present in hydrochloric acid sample solution does not affect the hydrogenation of As(III). Thus, the HF concentration must be controlled to avoid the formation of fluor-complexed ions, such as $\left[\mathrm{AsF}_{5} \mathrm{OH}\right]^{-}$, which do not react with $\mathrm{NaBH}_{4}$. These complexes can also be hydrolyzed by prolonged treatment with $\mathrm{HCl}^{21}$

\section{Effect of the oxidation state}

It is known that, using the batch system and a $\mathrm{pH} \leq 1$, the arsine is formed more slowly from $\mathrm{As}(\mathrm{V})$ than from As(III). ${ }^{21}$ This results in peak heighs that are 25 to $30 \%$ lower for $\mathrm{As}(\mathrm{V})$, but peak areas are approximately the same for both species. ${ }^{21}$ In this way, pre-reduction of $\mathrm{As}(\mathrm{V})$ can be omitted for simplicity when these species are present after sample treatment, if peak area is used for quantification, as it was the case in this work.

\section{Figures of merit and analytical application}

Calibration curve, using As(III) standard solutions in the concentration range 5-50.0 $\mu \mathrm{g} \mathrm{L}{ }^{-1}$, was obtained, using the optimized conditions and acid medium employed in the preparation of the slurry. The obtained correlation coefficient 
$\left(r^{2}\right)$ was 0.9997 and the slope was $0.0612 \mathrm{~s} \mathrm{~L} \mu g^{-1}$. The limit of detection (LOD), calculated as three times the standard deviation of ten measurements of the blank divided by the slope of the calibration curve, was $0.6 \mu \mathrm{g} \mathrm{g}^{-1}$. This detection capacity was adequate for the analysis of the certified sediments, using the proposed slurry preparation procedure. The accuracy of the procedure was verified by determining As in five certified sediment samples. As shown in Table 1, the found concentrations are in agreement with the certified values, according to the $t$-test for a confidence level of $95 \%$. The relative standard deviations (RSD), which are also shown in Table 1, were lower than $13 \%$ for four of the five samples, indicating an adequate precision for slurry sampling in this concentration range. Certainly, real samples of sediment could also be analyzed, since the concentrations found in another work ${ }^{19}$ for samples collected in three locations around the Santa Catarina Island, Brazil were at least ten times above the LOD found in this work.

Table 1. Analytical results for arsenic determination in certified reference sediment using slurry sampling HG-AAS. Obtained values (average \pm standard deviation) in $\mu \mathrm{g} \mathrm{g}^{-1}$ and $\mathrm{n}=3$

\begin{tabular}{lccc}
\hline Samples & Certified & Determined & RSD $(\%)$ \\
\hline RS-3 & $16.4 \pm 0.50$ & $16.1 \pm 0.7$ & 4.3 \\
PACS-2 & $26.2 \pm 1.50$ & $25.6 \pm 3.4$ & 13.3 \\
SRM 2704 & $23.4 \pm 0.80$ & $23.3 \pm 2.7$ & 11.6 \\
SRM 1646a & $6.23 \pm 0.21$ & $6.24 \pm 1.17$ & 5.6 \\
MESS-2 & $20.7 \pm 0.80$ & $19.8 \pm 0.41$ & 2.1 \\
\hline
\end{tabular}

The good results obtained is an indication that almost $100 \%$ of the analyte in the sample reacts with the reducing agent, indicating an effective extraction of the analyte to the aqueous phase aided by the acid medium of the slurry and also by the reactions with the reducing agent. Kinetic effects from As species with different oxidation states were accounted for, as integrated signals were used.

\section{Conclusions}

Slurry sampling combined with the classical arsine generation atomic absorption spectrometry showed to be a simple method for the quantitative analysis of sediments with adequate precision and accuracy. The standing time is a very important parameter to obtain accurate results. Slurry sampling avoids analyte loss and is very simple, not requiring special instrumentation for sample preparation. Certainly, the method is applicable to other environmental samples.

\section{Acknowledgments}

The authors are thankful to the Conselho Nacional de Pesquisas e Desenvolvimento Tecnológico (CNPq) and to the Financiadora de Estudos e Projetos (FINEP) for financial support. The authors have research scholarships from CNPq.

\section{References}

1. Hudson-Edwards, K. A.; Houghton, S. L.; Osborn, A.; Trends Anal. Chem. 2004, 23, 745.

2. Azevedo, F. A.; Chasin, A. A. M.; Metais: Gerenciamento da Toxicidade, $1^{\text {st }}$ ed., Atheneu: São Paulo, 2003.

3. Pataca, L. C. M.; Botoleto, G. G.; Bueno, M. I. M. S.; Quim. Nova 2005, 28, 579.

4. Barra, C. M.; Santelli, R. E.; Abrão, J. J.; de la Guardia, M; Quim. Nova 2000, 23, 58.

5. Dědina, J.; Tsalev, D. L.; Hydride Generation Atomic Absorption Spectrometry, John Wiley: Chichester, 1995.

6. Moretto, A. L.; Cadore, S.; Mikrochim. Acta 2004, 146, 239.

7. Guo, X.; Sturgeon, R. E.; Mester, Z.; Gardner, G. J.; Anal. Chem. 2004, 76, 2401.

8. Guo, X.; Sturgeon, R. E.; Mester, Z.; Gardner, G. J.; J. Anal. At. Spectrom. 2005, 20, 702.

9. Bendicho, C.; Loos-Vollebregt, M. T. C. de; J. Anal. At. Spectrom. 1991, 6, 353.

10. Alves, F. L.; Smichowski, P.; Farías, S.; Marrero, J.; Arruda, M. A. Z.; J. Braz. Chem. Soc. 2000, 11, 365.

11. Alves, F. L.; Cadore, S.; Jardim, W. F.; Arruda, M. A. Z.; J. Braz. Chem. Soc. 2001, 12, 799.

12. Borges, D. L. G.; Dias L. F.; Da Veiga, M. A. M. S.; Curtius, A J.; J. Braz. Chem. Soc. 2003, 14, 291.

13. Ribeiro, A. S.; Vieira, M. A.; Curtius A. J.; J. Braz. Chem. Soc. 2004, 15, 825.

14. Haswell, S. J.; Mendham, J.; Blutler, M. J.; Smith, D. C.; J. Anal. At. Spectrom. 1988, 3, 731.

15. Mierzwa, J.; Dobrowolski, R.; Spectrochim. Acta Part B 1998, $53,117$.

16. Gürleyük, H.; Tyson, J. F.; Uden, P. C.; Spectrochim. Acta Part B 2000, 55, 935.

17. Matusiewicz, H.; Sturgeon, R.E.; Spectrochim. Acta Part B 1996, 51, 377.

18. Matusiewicz, H.; Mroczkowska, M.; J. Anal. At. Spectrom. 2003, 18, 751 .

19. Vieira, M. A.; Welz, B.; Curtius, A. J.; Spectrochim. Acta Part B 2002, 57, 2057.

20. Heininger, P.; Pelzer, J.; Henrion, R.; Henrion, G.; Fresenius' J. Anal. Chem. 1998, 360, 344.

21. Petrick, K.; Krivan, V.; Anal. Chem. 1987, 59, 2476.

22. Welz, B.; Sperling, M.; Atomic Absorption Spectrometry, $3^{\text {rd }}$ ed., Wiley: Weinheim, 1999, 437.

Received: October 17, 2006 Web Release Date: June 19, 2007 